\title{
Blood purification could tackle COVID-19?
}

\author{
Hiroyuki Yamada ${ }^{1,2^{*}}$ and Shigeru Ohtsuru ${ }^{1}$
}

\begin{abstract}
Coronavirus disease 2019 (COVID-19) threatened human lives worldwide since first reported. The current challenge for global intensivists is to establish an effective treatment for severe COVID-19. Blood purification has been applied to the treatment of various critical illnesses. Theoretically, its technique also has an enormous possibility of treating severe COVID-19 in managing inflammatory cytokines and coagulopathy. Recent clinical studies have revealed the positive clinical effect of therapeutic plasma exchange. Other studies have also indicated the considerable potential of other blood purification techniques, such as Cytosorb, AN69 surface-treated membrane, and polymyxin b hemoperfusion. Further research is needed to elucidate the actual effects of these applications.
\end{abstract}

Keywords: Plasmapheresis, Plasma exchange, Cytosorb, Apheresis, AN69ST, Oxiris, PMX-DHP, Coronavirus, Pandemic, Cytokine

\section{Background}

Coronavirus disease 2019 (COVID-19) has been a new threat to humans since it was first reported in Wuhan, China. Despite the development of vaccines and medical treatment, a portion of COVID-19 patients become critically ill due to acute respiratory distress syndrome (ARDS) and other complications [1-4]. As recent basic studies indicate, these multiorgan dysfunctions mainly derive from three pathogeneses: cytokine storm, excessive inflammatory response, and hypercoagulation $[5,6]$. To tackle this global crisis, we need to establish a treatment to control these pathological mechanisms.

Blood purification is a type of therapy based on the extracorporeal treatment of blood [7]. It has been widely used to treat severe refractory disorders to conventional therapies, such as fulminant liver failure, collagen diseases, and transplant rejection [8]. These applications have theoretical backgrounds such as suppressing excessive inflammation, lessening the cytokine storm, and correcting the coagulopathy. Many physicians are

\footnotetext{
*Correspondence: hyamada@kuhp.kyoto-u.ac.jp

${ }^{1}$ Department of Primary Care and Emergency Medicine, Graduate

School of Medicine, Kyoto University, 54 Shogoin-kawaharacho, Sakyo-ku, Kyoto 6068507, Japan

Full list of author information is available at the end of the article
}

now wondering if this theoretical application could also be favorable in the treatment of patients with severe COVID-19. Based on this background, we focus on the positive possibility of blood purification in COVID-19.

\section{Main text}

Therapeutic plasma exchange

Therapeutic plasma exchange (TPE) is a blood purification therapy that efficiently separates the plasma from the blood cells and replaces it with fresh frozen plasma. Theoretically, the technique could both remove the pathological plasma with multiple cytokines and normalize the coagulopathy. Since the beginning of the COVID-19 pandemic, there have been case reports of the successful TPE treatment of patients with severe COVID-19 [9-12]. These reports also demonstrated improved cytokine concentrations and coagulation markers immediately after the TPE procedure [10-12]. Clinical studies were also initiated to examine the clinical effect of TPE on severe COVID-19 cases (Table 1).

Using a retrospective propensity score-matched analysis, Gucyetmez et al. compared the prognosis of COVID19 patients in the intensive care unit (ICU) between patients receiving standard therapy alone and patients receiving standard therapy plus TPE [13]. As in previous reports, this study showed that TPE decreased original author(s) and the source, provide a link to the Creative Commons licence, and indicate if changes were made. The images or other third party material in this article are included in the article's Creative Commons licence, unless indicated otherwise in a credit line to the material. If material is not included in the article's Creative Commons licence and your intended use is not permitted by statutory regulation or exceeds the permitted use, you will need to obtain permission directly from the copyright holder. To view a copy of this licence, visit http://creativecommons.org/licenses/by/4.0/. The Creative Commons Public Domain Dedication waiver (http://creativeco mmons.org/publicdomain/zero/1.0/) applies to the data made available in this article, unless otherwise stated in a credit line to the data. 
Table 1 Summary of the published studies investigating the effect of therapeutic plasma exchange for COVID-19

\begin{tabular}{|c|c|c|c|c|c|}
\hline Trials & Study design & $\begin{array}{l}\text { Sample } \\
\text { size (TPE/ } \\
\text { control) }\end{array}$ & TPE replacement fluids & $\begin{array}{l}\text { Number of TPE } \\
\text { treatment }\end{array}$ & $\begin{array}{l}\text { Results (mortality rate, } \\
\text { MV, LOS) }\end{array}$ \\
\hline Gucyetmez et al. [13] & $\begin{array}{l}\text { Retrospective study with } \\
\text { PSM }\end{array}$ & $12 / 12$ & Not mentioned & Not mentioned & $\begin{array}{l}\cdot \text { Mortality rate-mortality, } \\
8 \% \text { vs. } 58 \%, p<0.01 \\
\cdot \text { MV-duration of MV, } \\
316 \text { h vs. } 278 \text { h, } p=0.67 \\
\cdot L O S-C U \text { LOS, } 20 \text { days vs. } \\
14 \text { days, } p=0.07\end{array}$ \\
\hline Kamran et al. [14] & $\begin{array}{l}\text { Retrospective study with } \\
\text { PSM }\end{array}$ & $45 / 45$ & FFP: normal saline $=2: 1$ & Daily until recovery & $\begin{array}{l}\text { - Mortality rate-overall sur- } \\
\text { vival, } 91 \% \text { vs. } 62 \%, p<0.01 \\
\cdot \text { LOS-Total LOS, } 10 \text { days } \\
\text { vs. } 15 \text { days, } p=0.01\end{array}$ \\
\hline Khamis et al. [15] & Retrospective study & $11 / 20$ & FFP & 5 times & $\begin{array}{l}\cdot \text { Mortality rate-all-cause } \\
\text { mortality, } 9 \% \text { vs. } 45 \%, \\
p=0.055 \\
28 \text { day mortality, } 0 \% \text { vs. } \\
35 \%, p=0.033 \\
14 \text { day mortality, } 0 \% \text { vs. } \\
35 \%, p=0.033 \\
\cdot \text { MV-extubation, } 73 \% \text { vs. } \\
20 \%, p=0.02 \\
\cdot \text { LOS-total LOS, } 19 \text { days } \\
\text { vs. } 11 \text { days, } p=0.13 \\
\text { ICU LOS, } 14 \text { days vs. } 6 \text { days, } \\
p=0.03\end{array}$ \\
\hline Faqihi et al. [16] & $\mathrm{RCT}$ & $34 / 39$ & $\begin{array}{l}\text { FFP or artificial Ocyaplas } \\
\mathrm{LG}^{\circledR}\end{array}$ & Maximum of 5 times & $\begin{array}{l}\cdot \text { Mortality rate-35 day } \\
\text { mortality, } 21 \% \text { vs. } 34 \%, \\
p=0.09 \\
\cdot \text { MV—duration of MV, } \\
15 \text { days vs. } 19 \text { days, } p<0.01 \\
\cdot \text { LOS-ICU LOS, } 19 \text { days vs. } \\
26 \text { days, } P=0.02\end{array}$ \\
\hline
\end{tabular}

APACHE Acute Physiology and Chronic Health Evaluation, ARDS acute respiratory distress syndrome, FFP fresh frozen plasma, ICU intensive care unit, LOS length of stay, MDOS multiple organ dysfunction syndrome, $M V$ mechanical ventilation, TPE therapeutic plasma exchange, $P S M$ propensity score matching, $R C T$ randomized controlled trial

interleukin-6 (IL-6) and D-dimer levels. Additionally, among patients with higher D-dimer $(\geqq 2)$ levels, the TPE group had a significantly lower mortality rate (8\% vs. $58 \% ; p<0.01)$. Kamran et al. also applied a similar analysis to 280 COVID-19 patients and investigated the clinical effect of TPE [14]. They found that the TPE group's 28 -day survival rate was significantly superior (91\% vs. $62 \% ; p<0.01)$. The median duration of hospitalization was also reduced in the TPE group (10 days vs. 15 days; $p<0.01)$. These retrospective studies suggested that TPE could improve the laboratory markers and ameliorate the prognosis of severe COVID-19 cases [13-15].

To address the same clinical question, Faqihi et al. designed a randomized controlled trial (RCT) that compared standard therapy alone with standard therapy plus TPE [16]. Although the 35-day mortality rate was not significantly lower in the TPE group (21\% vs. $34 \%$, $p=0.09$ ), the duration of mechanical ventilation (15 days vs. 19 days; $p<0.01$ ) and ICU stay (19 days vs. 26 days; $p=0.02$ ) was significantly reduced. This RCT's results also supported the efficacy of TPE for severe COVID-19 cases.

\section{Cytosorb}

Cytosorb is a hemadsorption device that was approved in the European Union in 2011 for cytokine adsorption [17]. Its therapeutic impact on cytokine removal has been reported in various critical diseases, such as septic shock and cardiac surgery $[18,19]$. One feature of this device is that it permits combination with other extracorporeal blood treatments, including continuous kidney replacement therapy (CKRT) and extracorporeal membrane oxygenation (ECMO). The co-treatment efficacy of Cytosorb and venous-venous ECMO (V-V ECMO) for severe COVID-19 pneumonia has been investigated in several clinical studies [20-22].

Rieder et al. preliminarily revealed that the initiation of V-V ECMO with Cytosorb markedly decreased the IL-6 level of COVID-19 patients [23]. They performed an open-label, multicenter RCT to evaluate the effect 
of V-V ECMO and Cytosorb for severe COVID-19-related ARDS [24]. In contrast to their preliminary data, however, their RCT's results countered the authors' expectations [25]. Namely, the 30-day survival rate was considerably lower in the Cytosorb group (18\% vs. $76 \% ; p<0.01)$. Even the serum IL-6 level after $72 \mathrm{~h}$ was not significantly reduced $(99 \mathrm{pg} / \mathrm{mL}$ vs. $112 \mathrm{pg} /$ $\mathrm{mL} ; p=0.54)$. As such, they concluded that early Cytosorb initiation should be avoided in severe COVID-19 patients requiring $\mathrm{V}-\mathrm{V}$ ECMO.

It is of note, however, that this RCT's results have been questioned in regard to randomization, timing of ECMO, and serum IL- 6 concentrations $[26,27]$. Therefore, it might be premature to rush to negative conclusions about the efficacy of Cytosorb. There are other RCTs that are currently examining the effects, such as NCT04518969, NCT04344080, DRKS00021447, and further investigations are expected [28].

Modified AN69ST (Oxiris) and polymyxin b hemoperfusion Oxiris is a newly developed CKRT hemofilter with an AN69 surface-treated membrane [29]. It provides high absorbance of endotoxin (negatively charged) and excellent anti-thrombogenicity because of its positively charged polyethyleneimine coating and heparin grafting [30]. Several case series and studies have already reported the hemofilter's validity in reducing cytokine concentrations in COVID-19 patients [31-35].

Polymyxin b hemoperfusion (PMX-DHP) is another widely used blood purification therapy for septic shock patients [36]. The hemoperfusion therapy removes circulating endotoxins through the adsorption to polymyxin b-immobilized columns. Although the treatment efficacy was not supported by recent guidelines, some case series have shown the clinical value of PMXDHP for COVID-19 patients [37-40]. Other studies also revealed that PMX-DHP could decrease levels of IL-6 and other inflammatory chemokines [41].

Unfortunately, the efficacy of these two therapies has not yet been sufficiently examined with control studies or RCTs. In vitro examinations indicate that these techniques could calm cytokine storms, however, and future research is thus warranted.

\section{Conclusions}

Blood purification has excellent potential to fight the COVID-19 pandemic. TPE, in particular, could be help$\mathrm{ful}$ in the clinical management of cytokine storms and coagulopathy. The efficacy of other techniques has also been supported by several clinical and in vitro studies. Further research is needed to elucidate the actual effects of these applications.

\section{Abbreviations}

ARDS: Acute respiratory distress syndrome; CKRT: Continuous kidney replacement therapy; COVID-19: Coronavirus disease 2019; ECMO: Extracorporeal membrane oxygenation; ICU: Intensive care unit; PMX-DHP: Polymyxin b hemoperfusion; RCT: Randomized controlled trial; TPE: Therapeutic plasma exchange.

\section{Acknowledgements}

None.

\section{Authors' contributions}

HY wrote the manuscript. SO supervised the manuscript. Both the authors read and approved the final manuscript.

\section{Funding}

None.

Availability of data and materials

All descriptions are based on the published data.

\section{Declarations}

Ethics approval and consent to participate

Not applicable.

Consent for publication

Not applicable.

\section{Competing interests}

The authors declare that they have no competing interests directly relevant to this article. Out of this article, $\mathrm{HY}$, and $\mathrm{SO}$ received a grant from Japanese Society for the Promotion of Science KAKENHI: $21 \mathrm{~K} 16188$ and 21K09045, respectively.

\section{Author details}

${ }^{1}$ Department of Primary Care and Emergency Medicine, Graduate School of Medicine, Kyoto University, 54 Shogoin-kawaharacho, Sakyo-ku, Kyoto 6068507, Japan. ${ }^{2}$ Department of Nephrology, Graduate School of Medicine, Kyoto University, Kyoto, Japan.

Received: 19 October 2021 Accepted: 16 November 2021

Published online: 11 December 2021

\section{References}

1. COVID-19 Treatment Guidelines Panel. Coronavirus Disease 2019 (COVID-19) Treatment Guidelines. National Institutes of Health. https:// www.covid19treatmentguidelines.nih.gov/. Accessed 20 Sep 2021.

2. Bhimraj A MR, Shumaker AH, Lavergne V, Baden L, Cheng VC, Edwards KM, Gandhi R, Gallagher J, Muller WJ, O'Horo JC, Shoham S, Murad MH, Mustafa RA, Sultan S, Falck-Ytter Y. Infectious Diseases Society of America Guidelines on the Treatment and Management of Patients with COVID-19. Infectious Diseases Society of America 2021; Version 5.2.0. https://www.idsociety.org/practice-guideline/covid-19-guide line-treatment-and-management/. Accessed 20 Sep 2021.

3. Alhazzani W, Evans L, Alshamsi F, Møller MH, Ostermann M, Prescott HC, Arabi YM, Loeb M, Ng Gong M, Fan E, et al. Surviving sepsis campaign guidelines on the management of adults with coronavirus disease 2019 (COVID-19) in the ICU: first update. Crit Care Med. 2021. https://doi.org/ 10.1097/CCM.0000000000004899.

4. Yamakawa K, Yamamoto R, Ishimaru G, Hashimoto H, Terayama T, Hara Y, Hasegawa D, Ishihara T, Imura H, Okano H, et al. Japanese Rapid/Living recommendations on drug management for COVID-19. Acute Med Surg. 2021;8(1): e664.

5. Harrison AG, Lin T, Wang P. Mechanisms of SARS-CoV-2 transmission and pathogenesis. Trends Immunol. 2020;41(12):1100-15. 
6. Sun J, He WT, Wang L, Lai A, Ji X, Zhai X, Li G, Suchard MA, Tian J, Zhou J, et al. COVID-19: epidemiology, evolution, and cross-disciplinary perspectives. Trends Mol Med. 2020;26(5):483-95.

7. Ren J, Wei HL, Xu L, Jia LY. 5.55—Blood detoxication. In: Burlington M-YM, editor. Comprehensive biotechnology (second edition). Academic Press: Cambridge; 2011. p. 729-39.

8. Padmanabhan A, Connelly-Smith L, Aqui N, Balogun RA, Klingel R, Meyer E, Pham HP, Schneiderman J, Witt V, Wu Y, et al. Guidelines on the use of therapeutic apheresis in clinical practice-evidence-based approach from the writing committee of the American Society for Apheresis: the eighth special issue. J Clin Apher. 2019;34(3):171-354.

9. Keith P, Day M, Choe C, Perkins L, Moyer L, Hays E, French M, Hewitt K, Gravel G, Guffey A, et al. The successful use of therapeutic plasma exchange for severe COVID-19 acute respiratory distress syndrome with multiple organ failure. SAGE Open Med Case Rep. 2020;8: $2050313 \times 20933473$

10. Zhang L, Zhai H, Ma S, Chen J, Gao Y. Efficacy of therapeutic plasma exchange in severe COVID-19 patients. Br J Haematol. 2020;190(4):e181-3.

11. Morath C, Weigand MA, Zeier M, Speer C, Tiwari-Heckler S, Merle U. Plasma exchange in critically ill COVID-19 patients. Crit Care. 2020;24(1):481.

12. Liu J, Dong YQ, Yin J, He G, Wu X, Li J, Qiu Y, He X. Critically ill patients with COVID-19 with ECMO and artificial liver plasma exchange: a retrospective study. Medcine (Baltimore). 2020;99(26): e21012.

13. Gucyetmez B, Atalan HK, Sertdemir I, Cakir U, Telci L. Therapeutic plasma exchange in patients with COVID-19 pneumonia in intensive care unit: a retrospective study. Crit Care. 2020;24(1):492.

14. Kamran SM, Mirza ZE, Naseem A, Liaqat J, Fazal I, Alamgir W, Saeed F, Saleem S, Nisar S, Yousaf MA, et al. Therapeutic plasma exchange for coronavirus disease-2019 triggered cytokine release syndrome; a retrospective propensity matched control study. PLOS ONE. 2021;16(1): e0244853.

15. Khamis F, Al-Zakwani I, Al Hashmi S, Al Dowaiki S, Al Bahrani M, Pandak $\mathrm{N}$, Al Khalili H, Memish Z. Therapeutic plasma exchange in adults with severe COVID-19 infection. Int J Infect Dis. 2020;99:214-8.

16. Faqihi F, Alharthy A, Abdulaziz S, Balhamar A, Alomari A, AlAseri Z, Tamim $\mathrm{H}$, Alqahtani SA, Kutsogiannis DJ, Brindley PG, et al. Therapeutic plasma exchange in patients with life-threatening COVID-19: a randomised controlled clinical trial. Int J Antimicrob Agents. 2021;57(5): 106334.

17. Ankawi G, Xie Y, Yang B, Xie Y, Xie P, Ronco C. What have we learned about the use of cytosorb adsorption columns? Blood Purif. 2019;48(3):196-202.

18. Hawchar F, László I, Öveges N, Trásy D, Ondrik Z, Molnar Z. Extracorporeal cytokine adsorption in septic shock: a proof of concept randomized, controlled pilot study. J Crit Care. 2019;49:172-8.

19. Poli EC, Alberio L, Bauer-Doerries A, Marcucci C, Roumy A, Kirsch M, De Stefano E, Liaudet L, Schneider AG. Cytokine clearance with CytoSorb ${ }^{\circledR}$ during cardiac surgery: a pilot randomized controlled trial. Crit Care. 2019;23(1):108.

20. Alharthy A, Fagihi F, Memish ZA, Balhamar A, Nasim N, Shahzad A, Tamim $H$, Alqahtani SA, Brindley PG, Karakitsos D. Continuous renal replacement therapy with the addition of CytoSorb cartridge in critically ill patients with COVID-19 plus acute kidney injury: a case-series. Artif Organs. 2021:45(5):E101-e112.

21. Nassiri AA, Hakemi MS, Miri MM, Shahrami R, Koomleh AA, Sabaghian T. Blood purification with CytoSorb in critically ill COVID-19 patients: a case series of 26 patients. Artif Organs. 2021. https://doi.org/10.1111/aor. 14024.

22. Wunderlich-Sperl F, Kautzky S, Pickem C, Hörmann C. Adjuvant hemoadsorption therapy in patients with severe COVID-19 and related organ failure requiring CRRT or ECMO therapy: a case series. Int J Artif Organs. 2021:44: 3913988211030517.

23. Rieder M, Wengenmayer T, Staudacher D, Duerschmied D, Supady A. Cytokine adsorption in patients with severe COVID-19 pneumonia requiring extracorporeal membrane oxygenation. Crit Care. 2020;24(1):435.

24. Rieder M, Schubach F, Schmoor C, von Spee-Mayer C, Wengenmayer T, Rilinger J, Staudacher D, Bode C, Duerschmied D, Supady A. Cytokine adsorption in patients with severe COVID-19 pneumonia requiring extracorporeal membrane oxygenation: protocol for a randomised, controlled, open-label intervention, multicentre trial. BMJ Open. 2021;11(1): e043345.

25. Supady A, Weber E, Rieder M, Lother A, Niklaus T, Zahn T, Frech F, Müller

S, Kuhl M, Benk C, et al. Cytokine adsorption in patients with severe
COVID-19 pneumonia requiring extracorporeal membrane oxygenation (CYCOV): a single centre, open-label, randomised, controlled trial. Lancet Respir Med. 2021;9(7):755-62.

26. Rybalko A, Voronin AV, Karpun NA. Cytokine adsorption and ECMO in patients with COVID-19. Lancet Respir Med. 2021;9(8):e69-70.

27. Nardelli P, Pieri M, Fominskiy E, Scandroglio AM. Cytokine adsorption and ECMO in patients with COVID-19. Lancet Respir Med. 2021;9(8):e71-e71.

28. Stockmann H, Keller T, Büttner S, Jörres A, Kindgen-Milles D, Kunz JV, Leebmann J, Spies C, Träger K, Treskatsch S, et al. CytoResc - "CytoSorb" Rescue for critically ill patients undergoing the COVID-19 Cytokine Storm: a structured summary of a study protocol for a randomized controlled trial. Trials. 2020;21(1):577.

29. Hattori N, Oda S. Cytokine-adsorbing hemofilter: old but new modality for septic acute kidney injury. Renal Replacement Therapy. 2016;2(1):41.

30. Schwindenhammer V, Girardot T, Chaulier K, Grégoire A, Monard C, Huriaux L, Illinger J, Leray V, Uberti T, Crozon-Clauzel J, et al. oXiris ${ }^{\circledR}$ use in septic shock: experience of two French centres. Blood Purif. 2019:47:29-35.

31. Zhang H, Zhu G, Yan L, Lu Y, Fang Q, Shao F. The absorbing filter Oxiris in severe coronavirus disease 2019 patients: a case series. Artif Organs. 2020;44(12):1296-302.

32. Peerapornratana $S$, Sirivongrangson $P$, Tungsanga $S$, Tiankanon $K$, Kulvichit W, Putcharoen O, Kellum JA, Srisawat N. Endotoxin adsorbent therapy in severe COVID-19 pneumonia. Blood Purif. 2021. https://doi. org/10.1159/000515628.

33. Ugurov P, Popevski D, Gramosli T, Neziri D, Vuckova D, Gjorgon M, Stoicovski E, Marinkovic S, Veljanovska-Kiridjievska L, Ignevska K, et al. Early initiation of extracorporeal blood purification using the AN69ST (oXiris ${ }^{\circledR}$ ) hemofilter as a treatment modality for COVID-19 patients: a single-centre case series. Braz J Cardiovasc Surg. 2020. https://doi.org/10.21470/ 1678-9741-2020-0403.

34. Rosalia RA, Ugurov P, Neziri D, Despotovska S, Kostoska E, VeljanovskaKiridjievska L, Kuzmanov D, Trifunovski A, Popevski D, Villa G, et al. Extracorporeal blood purification in moderate and severe COVID-19 patients: a prospective cohort study. Blood Purif. 2021. https://doi.org/10.1159/ 000515627.

35. Villa G, Romagnoli S, De Rosa S, Greco M, Resta M, Pomarè Montin D, Prato F, Patera F, Ferrari F, Rotondo G, et al. Blood purification therapy with a hemodiafilter featuring enhanced adsorptive properties for cytokine removal in patients presenting COVID-19: a pilot study. Crit Care. 2020;24(1):605.

36. Shimizu T, Miyake T, Kitamura N, Tani M, Endo Y. Endotoxin adsorption: direct hemoperfusion with the polymyxin B-immobilized fiber column (PMX). Transfus Apher Sci. 2017;56(5):682-8.

37. Egi M, Ogura H, Yatabe T, Atagi K, Inoue S, Iba T, Kakihana Y, Kawasaki T, Kushimoto S, Kuroda Y, et al. The Japanese clinical practice guidelines for management of sepsis and septic shock 2020 (J-SSCG 2020). J Intensive Care. 2021;9(1):53.

38. Kuwana T, Kinoshita K, Hirabayashi M, Ihara S, Sawada N, Mutoh T, Yamaguchi J. PMX-DHP therapy for dyspnea and deoxygenation in severe COVID-19 pneumonia: a case series. Infect Drug Resist. 2021;14:1305-10.

39. Ishiwari M, Togashi Y, Takoi H, Kikuchi R, Kono Y, Abe S. Polymyxin B haemoperfusion treatment for respiratory failure and hyperferritinaemia due to COVID-19. Respirol Case Rep. 2020;8(9): e00679.

40. Kusaba Y, Izumi S, Takasaki J, Suzuki M, Katagiri D, Katsuno T, Matsumoto S, Sakamoto K, Hashimoto M, Ohmagari N, et al. Successful recovery from COVID-19-associated acute respiratory failure with polymyxin B-immobilized fiber column-direct hemoperfusion. Intern Med. 2020;59(19):2405-8.

41. Katagiri D, Ishikane M, Asai Y, Izumi S, Takasaki J, Katsuoka H, Kondo I, Ide S, Nakamura K, Nakamoto T, et al. Direct hemoperfusion using a polymyxin B-immobilized polystyrene column for COVID-19. J Clin Apher. 2021;36(3):313-21.

\section{Publisher's Note}

Springer Nature remains neutral with regard to jurisdictional claims in published maps and institutional affiliations. 